\title{
Peranan Pemimpin Lokal dalam Meningkatkan Kemampuan Kelompok (Kasus Kelompok Tani di Desa Pulo Kencana Kecamatan Pontang Kabupaten Serang)
}

\author{
Role of Local Leader to Improving the Ability Group \\ (Case of Pulo Kencana Farmers Group in Pontang Sub-District, Serang District)
}

\author{
Helda Ibrahim ${ }^{1}$, Majdah Zain ${ }^{2}$, Tamzil Ibrahim ${ }^{2}$ \\ ${ }^{1}$ Fakultas Pertanian, Universitas Islam Makassar, Makasar \\ ${ }^{2}$ Fakultas Pertanian, Universitas Hasanuddin, Makassar
}

\begin{abstract}
Local leaders have a role as opinion leaders and development agencies in supporting the realization of a dynamic group in improving the ability of groups related to communication, motivation, to facilitating and social contacts, knowledge of groups and foster group experience. Rural communities still face problems, especially individuals that have not been able to develop itself in enhancing the ability of the group through the role of local leaders. The purpose of this study is to identify the role of local leaders in improving the ability of a group. This research was conducted in the village of Pulo Kencana, helter subdistrict, Serang regency. The number of respondents was 45 respondents with tree of farmer groups. The results showed that the role of local leaders in improving the ability of the group is high. This is due to the behavior on the actions of the leaders in facilitating the communication, increasing the motivation of group members and facilitating the group.
\end{abstract}

Key words: local leaders, leaders role, groups ability

Abstrak

Pemimpin lokal memiliki peranan sebagai pemimpin opini dan agen pembangunan dalam mendukung terwujudnya kelompok yang dinamis dalam meningkatkan kemampuan kelompok yang berkaitan dengan komunikasi, motivasi, memfasilitasi dan kontak sosial, pengetahuan kelompok, dan menumbuhkan pengalaman kelompok. Masyarakat pedesaan masih menghadapi masalah khususnya individu yang belum mampu mengembangkan dirinya dalam meningkatkan kemampuan kelompok melalui peran pemimpin lokal. Tujuan penelitian ini adalah mengidentifikasi peranan pemimpin lokal di dalam meningkatkan kemampuan berkelompok. Penelitian ini dilakukan di Desa Pulo Kencana Kecamatan Pontang Kabupaten Serang. Jumlah responden adalah 45 responden dengan tiga kelompok tani. Hasil penelitian menunjukkan bahwa peran pemimpin lokal dalam meningkatkan kemampuan kelompok adalah tinggi. Hal ini disebabkan dari perilaku pada tindakan pemimpin dalam memperlancar komunikasi, meningkatkan motivasi anggota kelompok dan memfasilitasi kelompok.

Kata kunci: pemimpin lokal, peranan pemimpin, kemampuan kelompok

\section{Pendahuluan}

Salah satu program pembangunan masyarakat desa adalah mengatasi kemiskinan yang dalam implementasinya menggunakan pendekatan kelompok melalui pemberdayaan masyarakat miskin. Menurut Bryant dan White (1987), pemberdayaan dapat menumbuhkan kekuatan yang lebih besar kepada masyarakat untuk mengatasi kemiskinan. Awang (2004) mengemukakakan bahwa pemimpin lokal pada hakekatnya memiliki potensi sebagai agen pembangunan yang mendukung terwujudnya kelompok yang dinamis dan terjaga kelangsungannnya. Menurut Widyastuti dan Santiasih (Mubyarto, 2004) keberhasilan pemimpin lokal dalam mendinamiskan kelompok Dharma Tirta, yakni kelompok strategi pembangunan sarana irigasi pedesaan.

Berdasarkan hal tersebut serta mengacu pada pendapat Kartodirdjo (2007) mengemukakan bahwa pemimpin lokaldenganotoritastradisionalnyamempunyai pengaruh yang efektif dalam pelaksanaan berbagai macam program pembangunan, sehingga dapat dipahami bahwa dalam pelaksanaan Program IDT, pemimpin lokal desa diberi kepercayaan sebagai pendamping bagi kelompok setempat. Ditekankan pula bahwa pendamping yang paling efektif adalah pendamping yang berasal dari anggota masyarakat setempat.

Amanah(2009)menemukanbahwakelembagaan kelompok tani yang semakin kuat akan dapat mendorong meningkatnya kerja sama antara individu (kelompok) dengan pihak luar. Hal ini terkait dengan pola yang diterapkan berbagai kalangan masih bersifat keproyekan 
khususnya pada kelompok-kelompok tani. Pendekatan yang dilakukan lebih mengacu pada charity dan belum sepenuhnya menggiatkan potensi masyarakat untuk mandiri.

Seorang Pemimpin harus dapat melakukan sesuatu bagi anggotanya disesuaikan dengan jenis kelompokyangdipimpinuntukmendinamiskankelompok beserta tujuannya (Alfitri, 2002; Johson, 1994). Menurut Soetrisno (2008) bahwa kepemimpinan merupakan suatu kemampuan proses untuk mempengaruhi orang-orang agar berbuat sesuatu dalam rangka mencapai tujuan.

Untuk mencapai luaran penelitian maka pendayagunaan pemimpin lokal melalui kelembagaan lokal sangat penting. Maka dari itu itu dalam usaha mendinamiskan anggota kelompok maka peranan pemimpin lokal dianggap sangat penting dalam meningkatkan kemampuan masyarakat di perdesaan. Berpijak dari masalah ini maka pertanyaan penelitian yang dikaji secara khusus adalah (1) bagaimana karakteristik anggota kelompok? (2) bagaimana persepsi anggota kelompok terhadap pemimpin lokal? (3) bagaimana peranan pemimpin lokal dalam meningkatkan kemampuan kelompok? (4) hubungan antara pemimpin lokal, persepsi anggota kelompok terhadap pemimpin lokal dan kemampuan kelompok. Adapun tujuan penelitian adalah untuk: (1) mengidentifikasi karakteristik anggota kelompok, (2) mengidentifikasi persepsi anggota kelompok terhadap pemimpin lokal (3) mengidentifikasi peranan pemimpin lokal dalam meningkatkan kemampuan kelompok? (4) mengidentifikasi Hubungan antara pemimpin lokal, persepsi anggota kelompok terhadap pemimpin lokal dan kemampuan kelompok.

Dahama dan Bhatnagar (1980) mengemukakan bahwa pemimpin adalah seseorang yang secara spontan mempertimbangkan, menentukan, dan mempengaruhi dalam situasi yang spesifik, sedangkan kepemimpinan adalah proses mempengaruhi individu dalam suatu situasi tertentu. Menurut Carter (Yusuf, 2009) ada lima pola dalam mendefinisikan pemimpin, yaitu: pertama, pemimpin adalah seseorang yang menjadi fokus dalam perilaku kelompok; kedua, pemimpin adalah seseorang yang memiliki kemampuan memimpin kelompok yang mengarah ke tujuan kelompok; ketiga, pemimpin adalah seseorang yang dipilih oleh anggota kelompok; keempat, pemimpin merupakan seseorang yang mampu mendemonstrasikan pengaruhnya atas kelompok; kelima, pemimpin adalah seseorang yang terikat pada perilaku kepemimpinan. Merujuk hal ini, maka didefinisikan bahwa pemimpin adalah seseorang yang memiliki kemampuan mempengaruhi dan mengatur perilaku orang lain ke arah pencapaian tujuan.

Kehidupan masyarakat desa terdapat pemimpin masyarakatyang berasal dan dipatuhioleh masyarakatnya. Menurut Uphord(1987) pemimpin masyarakat disebut sebagai local leaders (pemimpin lokal). Depositario (Valera, 1987), kepemimpinan lokal merupakan produk dari kehidupan masyarakat. Kepemimpinan lokal kedudukannya bukan karena dirinya sendiri melainkan sebagai hasil dari interaksi anggota dalam satu kelompok atau masyarakat. Kepemimpinan lokal juga merupakan proses mempersuasi, mengarahkan, dan mengatur usaha-usaha anggota masyarakat, sumber daya dan potensi untuk mencapai tujuan bersama. Kepemimpinan lokal juga merupakan proses mempengaruhi secara interpersonal di antara anggota yang saling membutuhkan untuk mencapai tujuan yang diinginkan. Dengan demikian pemimpin lokal adalah seseorang yang dipilih dan diterima oleh masyarakatnya agar dapat membantu mereka dalam perubahan fungsional dalam masyarakat itu. Dalam penelitian ini, pemimpin lokal diberi pengertian sebagai seseorang yang berasal dan dipatuhi oleh masyarakat desa dimana dia berada, yang memiliki kemampuan mempengaruhi dan mengatur perilaku masyarakatnya ke arah pencapaian tujuan pembangunan masyarakat desa. Pranowo (2005) mengelompokkan pemimpin lokal dalam dua kelompok status kepemimpinan, yaitu pemimpin formal dan informal. Menurut Kartono (2004) pemimpin formal adalah orang yang oleh organisasi/ lembaga ditunjuk sebagai pemimpin, berdasarkan keputusan dan pengangkatan resmi untuk memangku suatu jabatan dalam struktur organisasi, dengan segala hak dan kewajiban yang berkaitan dengannya untuk mencapai sasaran organisasi.

\section{Peran pemimpin lokal}

Peran pemimpin lokal secara garis besar digolongkanmenjadiduaperan, yaitusebagaipemimpin opini dan sebagai agen pembangunan. Peranan sebagai pemimpin opini adalah mempengaruhi sikap-sikap atau perilaku yang nyata dari anggota masyarakat lainnya secara informal. Adapun peranan sebagai agen pembangunan adalah: pertama, membantu memperkenalkan upaya pembangunan masyarakat; 
kedua, membantu menyebarluaskan kegiatan maupun upaya penyuluhan yang dilakukan oleh agen pembangunan agar dapat menjangkau sasaran lebih banyak; ketiga, merumuskan kepentingan, yaitu membantu agen pembangunan dalam menjelaskan aspek-aspek pembangunan kepada masyarakat, dan membantu dalam mengarahkan kelompok pada kegiatan yang berkaitan dengan program pembangunan agar dapat memecahkan masalah yang dihadapi oleh masyarakat; keempat, menghubungkan, yaitu membantu agen pembangunan dalam berhubungan dengan orang-orang yang berpengaruh dan anggota masyarakat; kelima, mengawasi suatu pekerjaan yang sedang berlangsung kegiatan pembangunan. Selain itu juga membantu menentukan prosedur kerja sehingga sumber daya manusia maupun sumber daya lainnya dapat digunakan dengan maksimal; dan keenam, membantu mengatur kelompok dalam pelaksanaan program-program pembangunan masyarakat desa (Valera, 1987). Berkaitan dengan peran membantu mengatur kelompok-kelompok dalam pelaksanaan program pembangunan masyarakat desa tersebut, pemimpin lokal mendukung terwujudnya kelompok yang dinamis dan terjaga kelangsungannya melalui posisi pemimpin lokal sebagai pembina kelompok. Adapun peranan itu terdiri dari tiga macam, yaitu: (1) memperlancar komunikasi kelompok, (2) meningkatkan motivasi anggota kelompok, dan (3) memberikan fasilitas kelompok (Slamet, 2002).

\section{Metode Penelitian}

Penelitian ini dilaksanakan di Desa Pulo Kencana Kecamatan Pontang Kabupaten Serang Provinsi Banten. Desa Pulo Kencana merupakan sentra pengembangan pangan di Provinsi Banten dan merupakan lokasi pengembangan Program Pemberdayaan Petani melalui Teknologi dan Informasi Pertanian (P3TIP). Populasi penelitian adalah dua kelompok tani yang berjumlah 90 orang dari semua anggota sampel yang diambil secara gugus bertahap dengan alasan bahwa populasi yang letaknya sangat tersebar secara geografis. Sampel individu (anggota kelompok) diambil 45 orang dari sampel kelompok. Unit analisis penelitian ini adalah ketua kelompok, pengurus kelompok dan anggota kelompok yang diwakili oleh responden yang terpilih. Sampel kelompok berdasarkan tingkat kemampuan kelompok yaitu Kelompok Utama sebanyak dua kelompok yaitu A dan B, sedangkan Kelompok Pemula yaitu Kelompok $\mathrm{C}$ dengan pertimbangan bahwa kelompok Utama memiliki peranan pemimpin yang berbeda antara kelompok A dan B.

Berdasarkan sumbernya data yang dikumpulkan dalam penelitian ini meliputi data primer dan data sekunder. Data primer diperoleh dari kelompok yang menjadi sampel, seperti (X1) Informasi tentang karakteristik anggota kelompok; (X2) Persepsi anggota kelompok terhadap pemimpin kelompok; (Y1) Ketua kelompok tani sebagai pemimpin kelompok; dan (Y2) Tingkat kemampuan kelompok. Untuk melihat hubungan dapat dilakukan dengan teknik pengujian korelasi rank Spearman. Data yang dikumpulkan melalui penggunaan daftar pertanyaan, wawancara mendalam, pengamatan, dan kajian terhadap data sekunder melalui kantor desa dan kecamatan serta wilayah kerja penyuluh pertanian (Wkpp) setempat.

\section{Hasil dan Pembahasan}

\section{Gambaran umum wilayah penelitian}

Desa Pulo Kencana terletak di sebelah Utara Pulau Jawa yang memiliki ketinggian sekitar lima meter di atas permukaan laut (m dpl) dengan jenis tanah pada umumnya Hidromorf Kelabu, tekstur Lempung berpasir, porositas tinggi, PH keasaman di atas 5-5,9 dengan kemiringan antara 5-8,9 dimana ting-kat kesuburan tanah rendah, salinitas tinggi, kapasitas tukar yang rendah akibat kurangnya penggunaan pupuk organik. Tipe iklim bulan basah sekitar 3-6 bulan dan bulan kering berkisar 6-9 bulan dengan suhu rata-rata $30^{\circ} \mathrm{C}$ sehingga berada pada tipe iklim tergolong pada tipe E3. Untuk lebih jelasnya dapat dilihat pada Gambar 1.

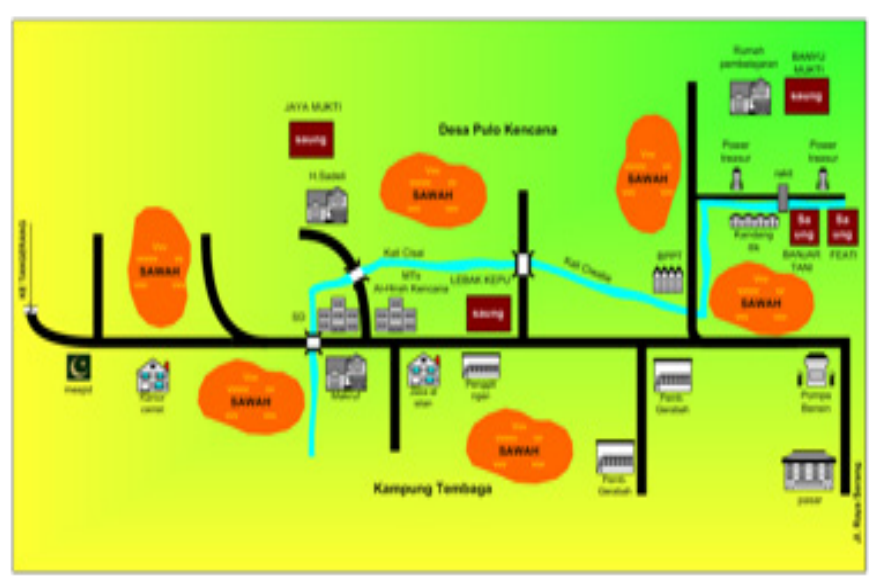

Gambar 1 Lokasi Penelitian 
Tabel 1 Karakteristik Anggota Kelompok Tani

\begin{tabular}{|c|c|c|c|c|c|}
\hline \multicolumn{2}{|c|}{ Kelompok } & $\begin{array}{c}\text { Kelompok A } \\
\quad \begin{array}{c}\text { (\%) } \\
\text { N }=15\end{array}\end{array}$ & $\begin{array}{c}\begin{array}{c}\text { Kelompok B } \\
(\%)\end{array} \\
\text { N=15 } \\
\end{array}$ & $\begin{array}{c}\text { Kelompok C } \\
\begin{array}{c}\text { (\%) } \\
\text { N=15 }\end{array}\end{array}$ & $\begin{array}{c}\text { Total }(\%) \\
\qquad \begin{array}{c}\mathrm{N}=45 \\
\end{array}\end{array}$ \\
\hline \multirow[t]{3}{*}{ Umur } & $\leq 39$ tahun & 0,00 & 0,00 & 33,33 & 11,11 \\
\hline & $40-54$ tahun & 73,33 & 80,00 & 60,00 & 71,11 \\
\hline & $\geq 55$ tahun & 26,67 & 20,00 & 6,67 & 17,78 \\
\hline \multirow[t]{3}{*}{ Pendidikan formal } & $\begin{array}{l}\text { Tak bersekolah, } \\
\text { tidak tamat SD }\end{array}$ & 0,00 & 0,00 & 0,00 & 0,00 \\
\hline & $\begin{array}{l}\text { SD, tidak tamat } \\
\text { SMP }\end{array}$ & 46,67 & 73,33 & 46,67 & 55,56 \\
\hline & SMP-SMA & 53,33 & 26,67 & 53,33 & 44,44 \\
\hline \multirow{3}{*}{$\begin{array}{l}\text { Pendidikan } \\
\text { non-formal }\end{array}$} & $\leq 4$ kali & 0,00 & 40,00 & 100,00 & 46,67 \\
\hline & $5-6$ kali & 93,33 & 46,67 & 0,00 & 46,67 \\
\hline & $\geq 7$ kali & 6,67 & 13,33 & 0,00 & 6,67 \\
\hline \multirow[t]{3}{*}{ Masa keanggotaan } & $\leq 2$ tahun & 0,00 & 0,00 & 100,00 & 33,33 \\
\hline & $3-4$ tahun & 0,00 & 0,00 & 0,00 & 0,00 \\
\hline & $\geq 5$ tahun & 100,00 & 100,00 & 0,00 & 66,67 \\
\hline
\end{tabular}

\section{Karakteristik Anggota Kelompok}

Secara umum karakteristik anggota kelompok tani sebagai anggota kelompok yang berhubungan dengan persepsi terhadap pemimpin lokal dapat dilihat pada Tabel 1. Karakteristik anggota dari segi umur sesuai dengan sasaran yang dituju oleh masing-masing kelompok, Tabel 1 memperlihatkan bahwa sebagian besar yang tergolong berumur sedang (40-54 thn), keadaan itu terjadi sebagai akibat tidak adanya sistem regenerasi kelompok. Sejak kelompok terbentuk belum pernah terjadi perubahan keanggotaan. Ratarata pada anggota kelompok memiliki pendidikan SD sampai dengan tamat SMP. Hal ini menggambarkan bahwa pendidikan formal untuk anggota kelompok masih dalam taraf rendah.

Untuk pendidikan non-formal pada anggota kelompok $\mathrm{C}$ masih dalam taraf yang rendah (masih berumur muda) hal ini disebabkan karena kelompok yang dibentuk masih dalam taraf baru. Berbeda pada kedua kelompok lainnya yakni A dan B sudah dalam taraftinggi, diakibatkan para anggota kelompok telah menjadi anggota sejak lama dan berpengalaman. Masa keanggotaan kelompok menunjukkan bahwa sebagian besar anggota kelompok termasuk lama, hanya pada kelompok A yang masih kategori rendah. Sebenarnya ini merupakan pemekaran dari kelompok tani B yang masa keanggotaannya sudah lama sama dengan masa keberadaan kelompok tersebut.

\section{Persepsi Anggota Kelompok terhadap Pemimpin Lokal}

Persepsi anggota kelompok terhadap pemimpin lokal dimaksudkan sebagai: (1) pengalaman pemimpin lokal membina, (2) pengetahuan pemimpin lokal tentang tujuan kelompok dan (3) kemampuan pemimpin berhubungan sosial. Persepsi anggota kelompok terhadap pemimpin lokal pada kelompok tani secara keseluruhan maupun parsial termasuk tinggi. Walaupun beberapa dari responden menunjukkan pada tingkat yang sedang, karena adanya kelemahan pemimpin lokal pada semua faktor tersebut. Untuk lebih jelasnya dapat dilihat pada Tabel 2.

Pada Tabel 2 memperlihatkan bahwa rata-rata skor dan standar deviasi dari segi pengalaman pemimpin lokal dalam membina kelompok itu bervariasi. Hal ini dilihat dari kelompok A yang memiliki standar deviasi tidak jauh berbeda dengan Kelompok B. Adapun kelompok $\mathrm{C}$ memiliki rata-rata skor rendah karena umur kelompok masih muda dan pengalaman di dalam membina kelompok masih baru. Kelompok A dan B memiliki pemimpin lokal yang berpengalaman dan banyak memiliki kelompok binaan lainnya. Hal ini karena besarnya kepercayaan masyarakat pada kemampuan tokoh strategis dalam membina kelompok 
Tabel 2 Persepsi Anggota Kelompok terhadap Pemimpin Lokal

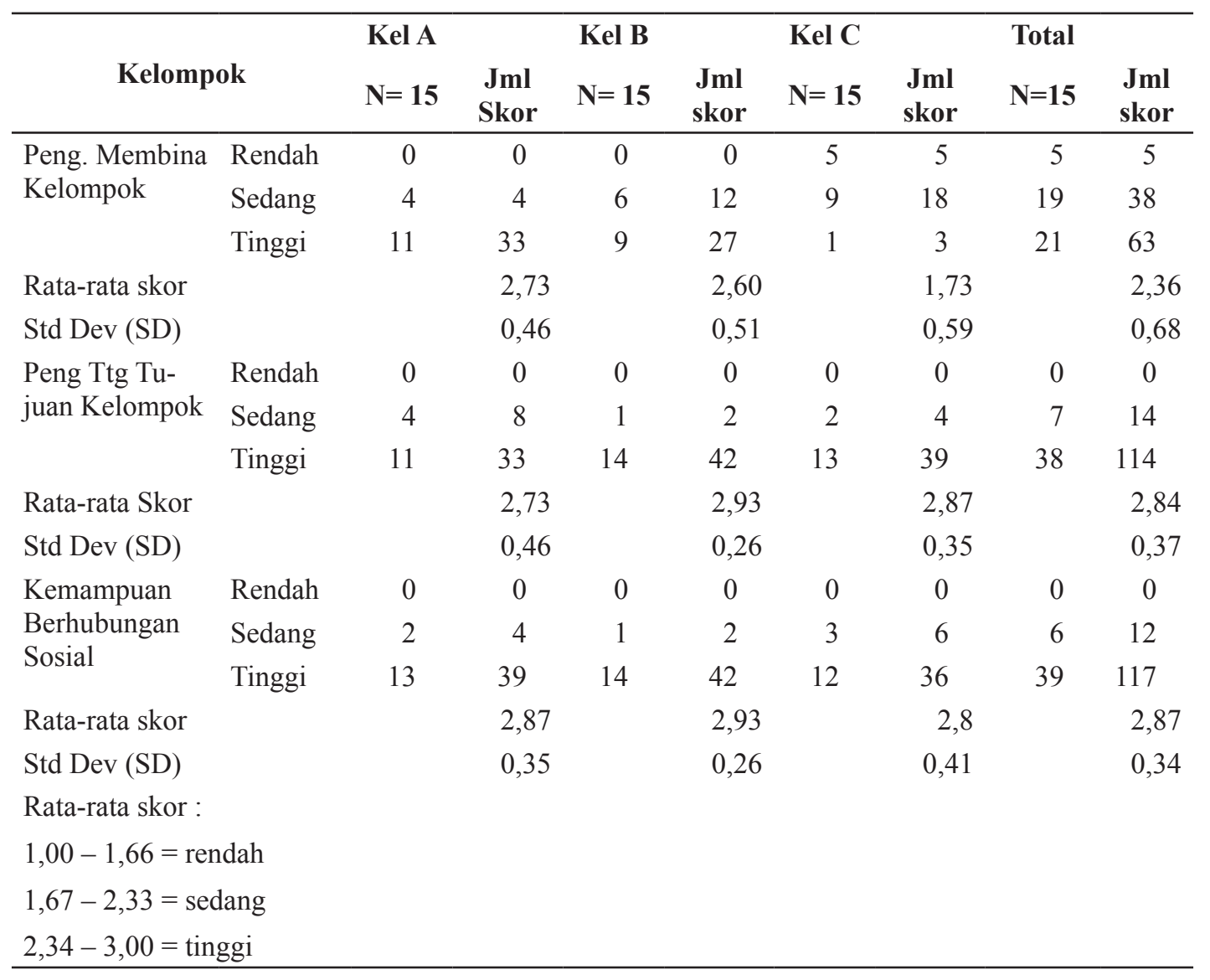

serta kurang lancarnya proses kaderisasi pada jabatan kelompok.

Pengetahuan pemimpin lokal tentang tujuan kelompok termasuk tinggi pada ketiga kelompok tani karena dapat mengemukakan tujuan dari kelompok tersebut dan kesadaran tumbuhnya kelompok berawal dari suatu kebutuhan yang terkait dengan kebudayaan masyarakat setempat berupa tradisi kegiatan tolongmenolong yang sudah mapan sehingga memerlukan wadah untuk memudahkan mobilitasi dan koordinasi dalam membentuk suatu kelompok. Kelompok C walaupun berumur muda, tetapi merupakan pengkaderan dari kelompok B. Kemampuan pemimpin lokal dalam berhubungan sosial termasuk tinggi pada semua kelompok baik secara keseluruhan maupun secara parsial. Hal ini menunjukkan bahwa pemimpin lokal dapat menciptakan situasi interaktif dalam setiap pertemuan kelompok.

\section{Peranan Pemimpin Lokal dalam Meningkatkan Kemampuan Kelompok}

Peranan pemimpin lokal dalam meningkatkan kemampuan kelompok dilihat dari perilaku pemimpin lokal dalam berperan sebagai Pembina kelompok melalui beberapa tindakan: (1) memperlancar jaringan komunikasi, (2) meningkatkan motivasi anggota kelompok, dan (3) memfasilitasi kelompok. Uraian hasil penelitiannya dapat dilihat pada Tabel 3. Tindakan pemimpin lokal dalam memperlancar komunikasi pada ketiga kelompok secara keseluruhan termasuk tinggi. Keadaan ini menunjukkan bahwa kontribusi pemimpin lokal dapat memperlancar komunikasi kelompok karena adanya kegiatan yang dapat digunakan sebagai wahana berkomunikasi sehingga dapat mempercepat laju informasi kelompok. Rata-rata skor dan standar deviasinya menunjukkan, bahwa tindakan pemimpin lokal dalam memperlancar komunikasi pada ketiga kelompok dimanfaatkan melalui kegiatan-kegiatan yang dilakukan sebagai media komunikasi kelompok.

Tindakanpemimpinlokaldalammeningkatkan motivasi anggota pada kelompok secara keseluruhan juga tinggi. Keadaan ini menunjukkan bahwa kontribusi pemimpin lokal pada masyarakat dapat meningkatkan motivasi anggota kelompok. Pada kelompok $\mathrm{C}$ transparansi tentang keuangan sangat 
Tabel 3 Peranan Pemimpin Lokal dalam Meningkatkan Kemampuan Kelompok

\begin{tabular}{|c|c|c|c|c|c|c|c|c|c|}
\hline & & \multicolumn{2}{|c|}{ Kel A } & \multicolumn{2}{|c|}{ Kel b } & \multicolumn{2}{|c|}{ Kel c } & \multicolumn{2}{|c|}{ Total } \\
\hline & & $N=15$ & $\begin{array}{l}\text { Jml } \\
\text { skor }\end{array}$ & $N=15$ & $\begin{array}{l}\text { Jml } \\
\text { skor }\end{array}$ & $N=15$ & $\begin{array}{l}\text { Jml } \\
\text { skor }\end{array}$ & $N=45$ & $\begin{array}{r}\text { Jml } \\
\text { skor }\end{array}$ \\
\hline \multirow{3}{*}{$\begin{array}{l}\text { Memperlancar } \\
\text { kom kelompok }\end{array}$} & Rendah & 0 & 0 & 0 & 0 & 0 & 0 & 0 & 0 \\
\hline & Sedang & 2 & 4 & 3 & 6 & 0 & 0 & 5 & 10 \\
\hline & tinggi & 13 & 39 & 12 & 36 & 15 & 45 & 40 & 120 \\
\hline Rata-rata skor & & & 2,87 & & 2,80 & & 3,00 & & 2,89 \\
\hline Std Dev (SD) & & & 0,35 & & 0,41 & & 0,00 & & 0,32 \\
\hline \multirow{3}{*}{$\begin{array}{l}\text { Meningkatkan } \\
\text { Motivasi } \\
\text { Kelompok }\end{array}$} & Rendah & 0 & 0 & 0 & 0 & 0 & 0 & 0 & 0 \\
\hline & Sedang & 2 & 4 & 1 & 2 & 0 & 0 & 3 & 6 \\
\hline & Tinggi & 13 & 39 & 14 & 42 & 15 & 45 & 42 & 126 \\
\hline Rata-rata skor & & & 2,87 & & 2,93 & & 3,00 & & 2,93 \\
\hline Std Dev (SD) & & & 0,35 & & 0,26 & & 0,00 & & 0,25 \\
\hline \multirow{3}{*}{$\begin{array}{l}\text { Memfasilitasi } \\
\text { kelompok }\end{array}$} & Rendah & 0 & 0 & 0 & 0 & 0 & 0 & 0 & 0 \\
\hline & Sedang & 0 & 0 & 3 & 6 & 4 & 8 & 7 & 14 \\
\hline & Tinggi & 15 & 45 & 12 & 36 & 11 & 33 & 38 & 114 \\
\hline Rata-rata skor & & & 2,87 & & 2,93 & & 2,80 & & 2,84 \\
\hline Std Dev (SD) & & & 0,35 & & 0,26 & & 0,41 & & 0,37 \\
\hline \multicolumn{10}{|l|}{ Rata-rata skor: } \\
\hline \multicolumn{10}{|c|}{$1,00-1,66=$ rendah } \\
\hline \multicolumn{10}{|c|}{$1,67-2,33=$ sedang } \\
\hline $2,34-3,00=\operatorname{tin}$ & & & & & & & & & \\
\hline
\end{tabular}

dijunjung tinggi sehingga meningkatkan semangat para anggota di dalam mengikuti kegiatan kelompok. Adapun untuk kelompok A dan B tindakan pemimpin lokal dalam meningkatkan motivasi anggotanya melalui kebijakan pemimpin lokal untuk memberikan kemudahan peminjaman uang bagi anggota yang aktif.

Tindakan pemimpin lokal dalam memfasilitasi kelompoksecarakeseluruhantermasuk kategoritinggi. Keadaan itu menunjukkan kontribusi pemimpin lokal pada kelompok ketiganya dapat memfasilitasi kelompok pada waktu diadakan kegiatan kelompok, diskusi dan pertemuan kelompok. Memfasilitasi kelompok yang dilakukan baik secara fisik maupun non fisik. Memfasilitasi secara fisik seperti tempat pertemuan kelompok, memberikan kemudahan di dalam membayar air atau menggunakan pompa trenser; sedangkan untuk memfasilitasi dari non fisik berupa adanya hubungan antara kelompok dan pembina dari luar.

Kemampuan Kelompok

Beberapa faktoryang diukur dalam meningkatkan kemampuan kelompok yaitu (1) perencanaan dalam kelompok, (2) usaha melakukan kegiatan, dan (3) melakukan koordinasi. Untuk lebih jelasnya dalapt dilihat pada Tabel 4. Pada kegiatan ini perencanaan kelompok tidak dilakukan khususnya pada $\mathrm{AD} / \mathrm{ART}$. Hal ini ditunjukkan dari setiap kelompok yang tidak memiliki aturan tertulis tentang bagaimana sebenarnya aturan main yang harus dilakukan dalam suatu kelompok, utamanya mengenai hak dan kewajiban dari anggota kelompok. Responden umumnya, tidak mengetahui kegunaan dari $\mathrm{AD} / \mathrm{ART}$ dan beranggapan bahwa itu tidak penting.

Selain itu juga tidak berfungsi dalam mendapatkan bantuan, atau kegiatan program tidak mensyaratkan adanya dokumen tersebut sehingga mereka tidak termotivasi untuk menyiapkannya. Hal ini terjadi disebabkan tidak ada biaya untuk melakukan penyiapan dokumen itu. Padahal jika dilihat dari kegiatan-kegiatan yang ada sebenarnya tidak terlalu memakan biaya yang penting ada kemauan untuk melakukan penyiapan ADRT. Meskipun tidak membutuhkan biaya dalam penyiapan dokumen, jika dalam melaksanakannya mereka mendapatkan imbalan (reward), maka mereka akan lebih termotivasi untu menyiapkan dokumen-dokumen tersebut. 
Tabel 4 Peranan Pemimpin didalam Kemampuan Kelompok

\begin{tabular}{|c|c|c|c|c|c|c|c|c|c|}
\hline & & \multicolumn{2}{|c|}{ Kel a } & \multicolumn{2}{|c|}{ Kel b } & \multicolumn{2}{|c|}{ Kel c } & \multicolumn{2}{|c|}{ total } \\
\hline & & $N=15$ & $\begin{array}{l}\text { Jml } \\
\text { skor }\end{array}$ & $N=15$ & $\begin{array}{l}\text { Jml } \\
\text { skor }\end{array}$ & $N=45$ & $\begin{array}{l}\text { Jml } \\
\text { skor }\end{array}$ & $N=15$ & $\begin{array}{l}\text { Jml } \\
\text { skor }\end{array}$ \\
\hline \multirow{3}{*}{$\begin{array}{l}\text { Perencanaan } \\
\text { kelompok }\end{array}$} & Rendah & 15 & 15 & 15 & 15 & 15 & 15 & 45 & 45 \\
\hline & Sedang & 0 & 0 & 0 & 0 & 0 & 0 & 0 & 0 \\
\hline & Tinggi & 0 & 0 & 0 & 0 & 0 & 0 & 0 & 0 \\
\hline Rata-rata skor & & & 1,00 & & 1,00 & & 1,00 & & 1,00 \\
\hline Std Dev (SD) & & & 0,00 & & 0,00 & & 0,00 & & 0,00 \\
\hline \multirow{3}{*}{$\begin{array}{l}\text { Usaha } \\
\text { melakukan } \\
\text { keg. kelompok }\end{array}$} & Rendah & 12 & 12 & 0 & 0 & 0 & 0 & 12 & 12 \\
\hline & Sedang & 3 & 6 & 12 & 24 & 4 & 8 & 19 & 38 \\
\hline & Tinggi & 0 & 0 & 3 & 9 & 11 & 33 & 14 & 42 \\
\hline Rata-rata skor & & & 1,20 & & 2,20 & & 2,73 & & 2,04 \\
\hline Std Dev (SD) & & & 0,41 & & 0,41 & & 0,46 & & 0,77 \\
\hline \multirow{3}{*}{$\begin{array}{l}\text { Koordinasi } \\
\text { kelompok }\end{array}$} & Rendah & 0 & 0 & 0 & 0 & 0 & 0 & 0 & 0 \\
\hline & Sedang & 0 & 0 & 3 & 6 & 2 & 4 & 5 & 10 \\
\hline & Tinggi & 15 & 45 & 12 & 36 & 13 & 39 & 40 & 120 \\
\hline Rata-rata skor & & & 3,00 & & 2,80 & & 2,87 & & 2,89 \\
\hline Std Dev (SD) & & & 0,00 & & 0,41 & & 0,35 & & 0,32 \\
\hline \multicolumn{10}{|c|}{ Rata-rata skor: } \\
\hline \multicolumn{10}{|c|}{$1,00-1,66=$ rendah } \\
\hline \multicolumn{10}{|c|}{$1,67-2,33=$ sedang } \\
\hline $2,34-3,00=$ ti & ggi & & & & & & & & \\
\hline
\end{tabular}

Hubungan antara Peranan Pemimpin Lokal, Persepsi Anggota Kelompok terhadap Pemimpin Lokal, dengan Kemampuan kelompok

Peranan pemimpin lokal, persepsi anggota kelompok dan kemampuan kelompok dapat dilihat pada Tabel 5. Aktivitas pemimpin lokal dalam meningkatkan kegiatan kelompok termasuk kategori sedang, kecualipadakelompokC. Halinimenunjukkan bahwa pemimpin lokal kurang dapat menciptakan kegiatan yang dapat mendukung tercapainya tujuan kelompok, bahkan pada Kelompok A pemimpin lokal tidak dapat menciptakan kegiatan yang efektif mendukung tercapainya apa yang diharapkan di dalam tujuan kelompok. Hal ini dikarenakan pemimpin lokal mengalami kendala, yaitu sering sakit sehingga tidak optimal untuk membina kelompok.

Kemampuan pemimpin lokal dalam melakukan koordinasi kelompok termasuk tinggi pada ketiga kelompok baik secara keseluruhan maupun secara parsial. Pemimpin lokal di dalam mengkoordinasi kegiatan-kegiatan kelompok ikut terlibat di dalam pelaksanaan dan berpartispasi secara sosial di antara kelompok-kelompok secara keseluruhan; sehingga dari kegiatan yang dilakukan selalu tampil yang terbaik dan mendapatkan bantuan program dari luar. Keterlibatan pemimpin dalam kegiatan merupakan bentuk apresiasi dan juga dukungan dari pemimpin terhadap anggota kelompoknya.

\section{Hubungan antara Persepsi Anggota terhadap Pemimpin Lokal dan Kemampuan Kelompok}

Persepsi anggota kelompok terhadap pemimpin lokal meliputi tiga faktor yaitu (1) pengalaman membina kelompok, (2) pengetahuan tentang tujuan kelompok, dan (3) kemampuan berhubungan sosial. Hubungan antara pengalaman membina kelompok dengan kemampuan kelompok dalam usaha melakukan kegiatan adalah nilai $r s=-0,458$ dan $p($ pada $\alpha=0,01)$ sebesar 0,002 . Artinya antara pengalaman membina kelompok dan kemampuan memiliki hubungan sangat nyata. Hal ini menunjukkan bahwa kemampuan kelompok ditentukan oleh pengalaman pemimpin lokal dalam membina kelompok. Sifat hubungan yang negatif menunjukkan bahwa kontribusi pengalaman 
Tabel 5 Hubungan antara Peranan Pemimpin Lokal dan Persepsi Anggota Kelompok terhadap Pemimpin Lokal dengan Kemampuan Kelompok

\begin{tabular}{|c|c|c|c|c|c|}
\hline \multicolumn{3}{|c|}{ Variabel } & \multicolumn{3}{|c|}{ Kemampuan kelompok } \\
\hline \multirow[t]{23}{*}{ Spearman's rho } & \multicolumn{2}{|c|}{ Persepsi } & $\begin{array}{c}\text { Petencanaan } \\
\text { kelompok }\end{array}$ & $\begin{array}{c}\text { Usaha } \\
\text { melakukan keg. }\end{array}$ & $\begin{array}{l}\text { Koordinasi } \\
\text { kelompok }\end{array}$ \\
\hline & \multirow{3}{*}{$\begin{array}{l}\text { Pengalaman } \\
\text { Membina } \\
\text { kelompok }\end{array}$} & $\begin{array}{l}\text { Correlation coef- } \\
\text { ficient }\end{array}$ & - & $-0,458 * *$ & $0,312^{*}$ \\
\hline & & Sig. (2-tailed) & - & 0,002 & 0,037 \\
\hline & & $\mathrm{N}$ & 45 & 45 & 45 \\
\hline & \multirow{3}{*}{$\begin{array}{l}\text { Pengetahuan } \\
\text { Membina } \\
\text { kelompok }\end{array}$} & $\begin{array}{l}\text { Correlation coef- } \\
\text { ficient }\end{array}$ & - & $-0,458 * *$ & 0,312 \\
\hline & & Sig. (2-tailed) & - & 0,002 & 0,037 \\
\hline & & $\mathrm{N}$ & 45 & 45 & 45 \\
\hline & \multirow[t]{3}{*}{$\begin{array}{l}\text { Pengetahuan ttg } \\
\text { tujuan kelompok }\end{array}$} & $\begin{array}{l}\text { Correlation coef- } \\
\text { ficient }\end{array}$ & - & 0,182 & $-0,152$ \\
\hline & & Sig. (2-tailed) & - & 0,233 & 0,320 \\
\hline & & $\mathrm{N}$ & 45 & 45 & 45 \\
\hline & \multirow{3}{*}{$\begin{array}{l}\text { Kemampuan } \\
\text { berhubungan } \\
\text { sosial }\end{array}$} & $\begin{array}{l}\text { Correlation coef- } \\
\text { ficient }\end{array}$ & - & $-0,062$ & 0,069 \\
\hline & & Sig. (2-tailed) & - & 0,687 & 0,651 \\
\hline & & $\mathrm{N}$ & 45 & 45 & 45 \\
\hline & \multicolumn{5}{|c|}{ Peranan pemimpin lokal } \\
\hline & \multirow{3}{*}{$\begin{array}{l}\text { Memperlancar } \\
\text { komunikasi } \\
\text { kelompok }\end{array}$} & $\begin{array}{l}\text { Correlation coef- } \\
\text { ficient }\end{array}$ & - & 0,113 & 0,100 \\
\hline & & Sig. (2-tailed) & - & 0,458 & 0,513 \\
\hline & & $\mathrm{N}$ & 45 & 45 & 45 \\
\hline & \multirow{3}{*}{$\begin{array}{l}\text { Meningkatkan } \\
\text { motivasi } \\
\text { kelompok }\end{array}$} & $\begin{array}{l}\text { Correlation coef- } \\
\text { ficient }\end{array}$ & - & 0,249 & $-0,094$ \\
\hline & & Sig. (2-tailed) & - & 0,099 & 0,537 \\
\hline & & $\mathrm{N}$ & 45 & 45 & 45 \\
\hline & \multirow[t]{3}{*}{$\begin{array}{l}\text { Memfasilitasi } \\
\text { kelompok }\end{array}$} & $\begin{array}{l}\text { Correlation coef- } \\
\text { ficient }\end{array}$ & - & $-0,214$ & $0,434 * *$ \\
\hline & & Sig. (2-tailed) & - & 0,157 & 0,003 \\
\hline & & $\mathrm{N}$ & 45 & 45 & 45 \\
\hline
\end{tabular}

membina kelompok yang tinggi dapat menurunkan kemampuan kelompok dalam melakukan kegiatan.

Adapun pengalaman membina kelompok dengan koordinasi kelompok nilai nilai rs $=0,312$ dan $p(\alpha=0,05)$ sebesar 0,037 dengan sifat hubungan yang positif. Artinya jika pengalaman dalam membina kelompok tinggi semakin meningkatkan koordinasi kelompok secara sangat nyata. Hal ini menunjukkan bahwa kemampuan kelompok di dalam persepsi anggota ditentukan oleh pengalaman pemimpin kelompok di dalam mewujudkan koordinasi kelompok.

Hubungan antara pengetahuan tentang tujuan kelompok dengan kemampuan kelompok dalam hal usaha melakukan kegiatan. menghasilkan nilai rs $=0,182$ dan $\mathrm{p}$ sebesar 0,233. Hal ini menunjukkan bahwa pengetahuan tentang tujuan kelompok tidak memiliki hubungan nyata dengan usaha melakukan kegiatan. Seperti halnya dengan pengetahuan tentang tujuan kelompok dengan koordinasi kelompok yang menghasilkan -0,152 dan p sebesar 0,320 menunjukkan bahwa pengetahuan tentang tujuan kelompok tidak memiliki hubungan nyata dengan koordinasi kelompok. Hal ini karena orang yang memiliki pengetahuan belum tentu dapat mengkordinasi kelompok karena pengetahuannya lebih diarahkan pada individu.

Hubungan antara kemampuan berhubungan 
sosial dengan usaha melakukan kegiatan, menghasilkan nilai $-0,062$ dan $\mathrm{p}$ sebesar 0,687 . Hal ini menunjukkan bahwa hubungan sosial dengan usaha melakukan kegiatan tidak berhubungan nyata. Lain halnya dengan hubungan sosial dengan koordinasi kelompok hasil analisis hubungan menghasilkan nilai 0,069 dengan sifat hubungan yang positif, tingkat hubugannya dapat dilihat bahwa semakin besar hubungan sosial maka akan semakin besar koordinasi kegiatan dapat dilakukan.

\section{Peranan Pemimpin Lokal}

Hubungan antara tindakan memperlancar komunikasi dengan kemampuan kelompok dalam usaha melakukan kegiatan nilai hasil hubungan tersebut sebesar 0,113 dengan nilai probalilitas $(p)$ sebesar 0,458 . Nilai $p$ lebih besar dari taraf nyata lima persen. Dari hasil tersebut dapat diketahui bahwa tidak ada hubungan yang nyata antara tindakan memperlancar hubungan komunikasi dengan kemampuan kelompok. Hubungan antara tindakan meningkatkan motivasi dengan usaha melakukan kegiatan kelompok tidak signifikan $(p=0,099)$ dengan nilai $r s=0,249$. Keadaan itu menunjukkan bahwa kontribusi pemimpin lokal dalam meningkatkan motivasi anggota belum dapat mendukung terciptanya koordinasi kelompok. Hubungan antara tindakan memfasilitasi dan kemampuan kelompok dalam usaha melakukan kegiatan menghasilkan nilai sebesar -0,214 dengan sifat hubungan yang negatif artinya bila kontribusi tindakan memfasilitasi semakin besar maka semakin kecil usaha melakukan kegiatan kelompok. Oleh karena itu tindakan tersebut kurang kontribusinya dalam mendukung terwujudnya melakukan kegiatan kelompok. Adapun hasil yang diperoleh antara memfasilitasi kelompok dengan kordinasi kelompok adalah $\mathrm{rs}=0,434$ yang memiliki hubungan positif. Artinya bila pemimpin lokal berkontribusi dengan memfasilitasi kelompok semakin besar maka semakin tinggi pula koordinasi kelompok Keadaan itu menunjukkan bahwa kontribusi pemimpin di dalam menfasilitasi kelompok memiliki hubungan yang nyata dalam meningkatkan koordinasi kelompok.

\section{Kesimpulan}

Faktor umur pada anggota kelompok tergolong sedang karena tidak adanya sistem regenerasi ketika menjadi anggota kelompok dan belum pernah ada perubahan keanggotaan. Pendidikan formal tergolong tinggi karena banyaknya pengalaman kegiatan walaupun termasuk dalam kelompok pemula. Persepsi anggota kelompok terhadap pemimpin lokal tergolong tinggi karena adanya pengalaman membina kelompok dan pengetahuan tujuan untuk berkelompok karena kesadaran tumbuhnya kelompok berawal dari kebutuhan yang terkait dengan kebudayaan masyarakat setempat.

Peranan pemimpin lokal dalam meningkatkan kemampuan kelompok tergolong tinggi karena adanya kontribusi pemimpin lokal dalam memperlancar komunikasi kelompok, meningkatkan motivasi anggota serta memfasilitasi kelompok di dalam kegiatan kelompok, pertemuan kelompok dan diskusi kelompok. Peranan pemimpin lokal dengan kemampuan kelompok berhubungan nyata khususnya pada pengalaman membina kelompok dan memfasilitasi kelompok. Hal ini disebabkan kelompok tani memiliki masa keanggotaan di atas 10 tahun dengan berbagai kegiatan yang telah dilakukan.

\section{Daftar Pustaka}

Alfitri. 2002. Kepemimpinan dan Struktur Kekuasaasn Lokal dalam pembangunan [Tesis]. Yogyakarta (ID): Universitas Gadjah Mada Yogyakarta.

Awang SA. 2004. Kemampuan dan Peranan KSM. Proses Keswadayaan (Studi kasus desa hutan dalam Keswadayaan Masyarakat Desa Tertinggal. Yogyakarta (ID): Aditya Media.

Amanah. 2009. Pengembangan Kelembagaan komunikasi inovasi kelompok tani Hortikultura dataran rendah dalam meningkatkan daya saing. PSP3. LPPM. Bogor (ID): Institut Pertanian Bogor.

Bryant, Coralie, White L. 1987. Manajemen Pembangunan untuk Negara berkembang. Jakarta (ID): LP3ES.

Dahama OP dan Batnagar OP. 1980. Education and Communication for Development. New Delhi: Oxford dan IBH Publishing Co.

Johnson DW. 1994. Joining Together: Group Theory dan Group Skills.Ed ke 3. Englewood Cliffs: Prentice Halls.

Kartodirdjo. 2007. Faktor-faktor endogen masyarakat pedesaan: Kepemimpinan, Kaderisasi, Komunikasi dan Lembaga-lembaga P3PK UGM. Yogyakarta 
(ID).

Kartono, Kartini. 2004 Pemimpin dan Kepemimpinan. Jakarta (ID): Raja Grafindo Persada.

Mubyarto. 2004. Reformasi Agraria: Menuju Pertanian Berkelanjutan. Jurnal Ekonomi Rakyat, 1(8) : 2025.

Pranowo DH. 2005 Masyarakat Desa: Tinjauan Sosiologi. Surabaya (ID): Bina Ilmu Surabaya.

Slamet. 2008. Kelompok : Kumpulan Bahan Bacaan. Edisi Ketiga. Bogor (ID): Institut Pertanian Bogor.

Soetrisno. 2008. Kelompok sebagai suatu strategi Pembangunan Pedesaan: Suatu pemikiran Kritis " Makalah tidak diterbitkan. XX (tidak direview?!)
Uphord PQ. 1987 Local Leadership and Programme Implementation in Indonesia. Amsterdam: Free University Press.

Valera JB et al. 1987. Extension Delivery Systems: An Introduction. Manila: Island Publishing House. Inc.

YusufY. 2009. Dinamika Kelompok: Kerangka Studi dalam Perspektif Psikologi Sosial. Bandung (ID): Armico. 